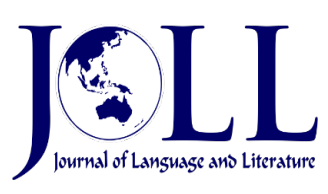

Vol. 21 No. 2, October 2021, pp. 349-361

DOI: 10.24071/joll.v21i2.3168

Available at https://e-journal.usd.ac.id/index.php/JOLL/index

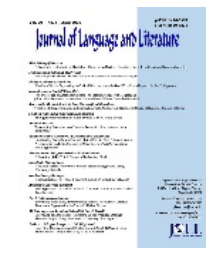

This work is licensed under a Creative Commons Attribution-ShareAlike 4.0 International License.

\title{
Hybridity and the Shape of the New African Woman
}

\author{
Regie P. Amamio \\ rui101519@yahoo.com \\ Department of English and Literature, Silliman University, Mindanao State University-GSC, \\ PHILIPPINES
}

\begin{abstract}
Hybridity is argued as an intricate combination of attraction and repulsion that describes the relationship between the colonizers and the colonized. This combination creates a challenge to and disruption of the monolithic power exercised by the colonizers of Africa who (mis)represented the land as a Dark Continent. Such monolithic power underpins the portrayal of the colonizers' patriarchal tradition within which women characters in creative works by Africans are commonly situated. The inclusion of women as part of the many subjects of power strengthens the discourse on hybridity in African literature. To question power is to see men and women both apart and together as ambivalence that defines the idea of hybridity in the African literary tradition. In this paper, the employment of deconstruction in the analysis of women characters in five selected stories by African writers reveals a new consciousness in African literature using the Dark Continent metaphor as a mirror of the female aesthetics. In this sense, the use of women's bodies in the short stories does not only point to the issue of gender oppression but also to a power that is disrupting and slowly dismantling the long-entrenched patriarchal stance forcing the male characters to question their current worldview and position. Overall, this paper has established that contemporary African literature on women recognizes the hybridized identity and shape of the new woman, consequently proving that the so-called Dark Continent is nothing but a myth.
\end{abstract}

\author{
Article \\ information \\ Received: \\ 3 March \\ 2021 \\ Revised: \\ 2 June \\ 2021 \\ Accepted: \\ 8 June \\ 2021
}

Keywords: Dark Continent metaphor; African women's bodies; deconstruction; hybridity

\section{Introduction}

African literature, which has a long, rich tradition, has often been considered through its different characteristics and categorization: by ethnicity; by region; by nationality; by the language of expression where verbal artistry is enjoyed through local languages such as Kiswahili and Amharic by bards, scribes, storytellers and poets; by genre; and by themes or generations (Diop in Okafor, 1997). But, of late, there is a shift from this prevailing 
literary terrain towards a greater social awareness resulting in an increased number of women writers (a revolutionary development given that women in most parts of Africa do not enjoy the same rights as given to men), increased production of both oral and written literature in African national languages such as Zulu and Yoruba, and increased critical attention and/or concentration on political and social writings.

This shift spotlights the diversity and complexity of life in the African continent reflecting the different literary traditions, social and political realities, and the everwidening and intensifying consciousness toward innovation. It also implies that the context of African literature must be seen in its totality which includes its history, its level of development, and the productive forces that have turned African literary production into a celebration of anti-colonial consciousness. In this sense, the issue of apartheid and other forms of African oppression due to the "myth of the Dark Continent" as perpetrated by their western colonizers has become one theme in African Literature, and the assertion of values that symbolize the distinctive African identities as another theme (Brantlinger, 1985).

These predominant themes from the new African literary terrain have created an impetus in restoring pride and honor in the black African traditions and, at the same time, a view of African literature as sensual and emotional in contrast to Western rationalism (Jarosz, 1992). It has also revealed ambiguities leading many writers to question the whole nationalistic envisioning in writing, to move away from the usual realistic narratives to more experimental and fragmentary styles as well as to emphasize the new theme of hybridity establishing it as a significant concept in African Literature commonly associated with colonialism.

The concept of hybridity is critical in postcolonial discourse due to its broad crosscultural backdrop and its negation of the inequality of power relations. Guignery, PessoMiquel, and Specq (2011) concur with this idea although they argue that the notion of hybridity really is unstable and may be better understood in the contexts of identity, nationhood, language, and culture. Bhabha (1994) has explored the term vis-à-vis the new literary direction in Africa concluding that there is a "convoluted combination of attraction and repulsion that characterizes the relationship between the colonizers and the colonized (p.85)." For him, these two contrasting terms neither necessarily resist nor complement each other. Instead, they become ambivalent or two-powered, which means the complicity and resistance that exist in a fluctuating relation within the colonial subject is seen to be both exploitative and nurturing or even only nurturing. Such ambivalence, according to Ghasemi, Sasani, and Nemati (2018), is nurturing on the part of the colonial subject because with the emergence of hybridity, the authority of the colonizer is destroyed. They argue that though hybridity may be a sign of the colonial power's productivity, it is also a sign of shifting of forces and fixities and a strategic reversal of the process of domination, which is disadvantageous to the colonizer. Farahbakhsh and Sheykhani (2018) affirm this idea after exploring Homi Bhabha's notion of ambivalence in J. M. Coetzee's Disgrace. Their study shows that ambivalence destabilizes the discourse of colonial authority and discloses the uncertainties and anxieties within colonial powers.

In another study, Sasani (2015) regards the relationship of the colonizer and the colonized as nurturing for as long as both presume that their relationship is mutually beneficial. He articulates Huddart's (2007) concept stating that "colonialism is marked by a complex economy of identity in which colonized and colonizer depend on each other (p. 22)." But chances are that imbalance and further tension will occur if the colonizers become intimidated by the colonized's new position (who also make the same assumption), which might acquire the latter equal power becoming their colonial double in the process. According to Bhabha (in Mambrol, 2016), this situation reflects the contrasting existence of attraction and repulsion in hybridity which produces an issue of power that eventually results in the authority's own destruction, creating an ambivalent situation nuanced with contestations of power. 
Such an ambivalent situation is not a simple reversal of binaries because both the colonizer and the colonized subjects are involved in propagating the ambivalence of colonial discourse. For instance, Yazdiha (2010) claims that hybridity counters essentialism and offers the opportunity for a counter-narrative. He further argues that it has the ability to empower marginalized collectives and deconstruct bounded labels which are used in perpetrating subordination. Thus, this ambivalence has the prospective to allow the once marginalized, repressed collectives to reclaim a part of their cultural space. This idea is supported by Jamshidian (2019) who states that through hybridity (represented by hybrids who assert their voices in the third space), the marginalized groups not only can survive and preserve their local heritage and identity despite the imperial pressures but can also affect the dominant power themselves. In brief, hybridity is not presented as a means of division to individualize identities, but rather as a means of re-imagining an interconnected collective.

Although the paradigm constructed through hybridity supplements discourses of cultural rights and global citizenship, it at the same time opens the exploration on the issue of the depths of power (Huddart, 2007). Similarly, the concept of ambivalence not only looks at the colonizer-colonized issue, but also at power as a whole being dismantled, subverted, and disturbed through deconstruction. In this context, Kourtti (2007) maintains that hybridity outlines strategic ways of diasporic and gendered resistance against colonial hierarchies and patriarchal dominance in post-colonial Africa, which become a kind of cultural translation possessing and re-possessing the past and the present in a constructive and meaningful way. African women who are part of the marginalized are thus explored and, at the same time, given a voice and platform to express themselves. Their male counterparts are not totally excluded since the telling of the latter's stories serves to highlight issues and changes in society. For instance, Friedman (2006) used Joyce Carol Oates' male characters in her paper to chart how changing ideologies of masculinity serve feminist purposes as well as to spotlight some cultural ideas relative to the male/female binary.

In the above context, this paper explores the Africa-as-a-woman metaphor discourse through the analysis of the following short stories: The Stranger by Abd Al-Majid Ben Jallun; A Man Can Try by Eldred Durosimi Jones; Coffee for the Road by Alex La Guma; $A$ Day Off by Anthony Hokororo; and A Meeting in the Dark by James Ngugi. These five works are all by male writers attempting to depict women's consciousness and the feminine tradition within the African power structure, thereby, contributing to the conversation on hybridity in African Literature.

\section{Methodology}

This paper is a qualitative study that utilizes content analysis based on poststructuralist or deconstructionist concepts by Derrida. Deconstruction rejects the notions of objective reality, objective truth, and the objective existence of texts arguing that no such thing as a "fixed representation of reality" exists, approximating Homi Bhabha's concept of hybridity. Hybridity stands in opposition to the myth of purity and racial and cultural authenticity of a fixed and essentialist identity. Bhabha's concept thus spotlights the idea of an idealized form of purity that is subverted, dismantled, and disturbed through the use of deconstruction. Specifically, five selected stories by African male writers are analyzed to perorate on the African women's consciousness and the feminine tradition within the African power structure, thereby contributing to the conversation on hybridity in African Literature. Within this power structure, the men represent power both as male characters (literally) and as the power wielded by the West (figuratively) while the women represent Africa both as female characters (literally) and as a metaphor for the motherland (figuratively).

\section{Results and Discussion}

African Literature through the works of five male writers depicts hybridity as an exploration of the power structure that elevates women's position undermining men's previously held dominance in the process. 


\section{The Maxim of Undecidability in African Literature}

The "maxim of undecidability" was employed by poststructuralists to counter the structuralists' assumption, grounded in Saussure's notion of langue (overall system), that accounts for a single interpretation of the text (parole) positing that a text has many meanings and therefore no definitive interpretation (Bressler, 1999).

This undecidability of meaning argues against the belief in objective reality, objective truth, and the objective existence of texts for no such thing as a "fixed representation of reality" exists. Instead, all expressions and descriptions of truth are subjective; these are simply creative inventions of the mind. Therefore, truth itself is relative, depending on the various cultural and social influences in a person's life. This poststructuralist argument aligns with Bhabha's (1996) concept of hybridity, which asserts that "hybridity stands in opposition to the myth of purity and racial and cultural authenticity of fixed and essentialist identity." Such a notion adopts harmony by combining different systems and encourages the complex, the impure, the heterogeneous, and the eclectic thus debunking an idealized form of purity.

The shaping of the idealized form of purity or the notion of "fixed representation of reality" in Africa can be traced back to when the powerful imperial impulses were at work, setting the standards for distinguishing what is evil and unethical from what is good and acceptable. These standards resulted in the ambivalence on Africa's distress and in the conflicting discernments of identity with Africans struggling to understand both their old self and new self as well as grappling with the uncertainty of their new role in the society. Such ambivalence is often manifested in contemporary African short stories.

In Jallun's The Stranger, for instance, a devious Frenchman named Andre arrives in Morocco pretending as a beggar to deceive the townspeople intending to, later on, usurp the local leadership. Andre is first presented as a Moroccan in a French body, but later on, exposed as a Frenchman in Moroccan land - two conflicting ideas that are metaphors of the conqueror's motive and imperial interest. Readers might first consider Andre as a pitiful man who is saved by Africa and a stranger who becomes attuned to the Moroccan ways. His adoption of the local practices initiates him to become part of the community - gaining the acceptance and trust of everyone. In the course of his stay in Morocco, Andre pretends sincere interest in local ways carefully hiding his true self - a man with an imperial mind and prejudiced heart against the Africans. As an imperialist, he is clear with his intent to gain power over the locals long before he arrived in Morocco. It is then not Andre who develops an uncertainty of role in the society but the Moroccans who are later on forced to live a degraded life after Andre usurps power. The townspeople struggle to abide by the rules of their new leader and after some time, feel not just resentment but terror as well of being killed, of their women being violated, of their land being despoiled, and of their tradition being desecrated.

The idea of uncertainty is also illustrated in Ngugi's Meeting in the Dark. The protagonist, John, struggles with his self-portrayal between being a Kenyan scholar steeped in his village's traditional beliefs and practices and being a son of a clergyman, a convert who practices and preaches the whites' ways and beliefs. John thinks he should establish his identity because he believes he cannot simply be both and is always in a dilemma as to which practices following. John is soon to leave for Uganda to finish his education and is expected to come back as a respectable son of Limuru. The tension to become the latter is heightened when John witnesses the demise of the old ways in Limuru embodied by young men like him transgressing their sacred tradition with their liberal sexual practices - bringing back wives from the land of the whites and impregnating local girls who are left with fatherless children when they go away. John himself is not guilt-free since his father practices the colonizers' religion contributing to Limuru's destruction. Eventually, he, too, commits his own cultural transgressions.

What can be argued in both the Moroccans' and John's positions is the volatility of the hierarchies they are in. The 
status quo is disturbed, tainted, and forever changed by situations beyond their control although the aftermath proves different for the respective protagonists. The Moroccans successfully emancipate themselves from physical, moral, and mental slavery. John, on the other hand, from an essentially emancipated fellow at the start ends up being a slave of his inability to choose between the old life and the new ways. He imagines his impending doom in this passage: "I, John, a priest's son, respected by all and is going to college, will fall, fall to the ground (p. 97)." The trouble with John is that "his imagination magnified the fall from the heights of goodness out of all proportions ( $p .101)$ " and that he has no firm convictions. He fears what his father and the people in the village will say and so is indecisive about whether to fight or not for the girl he loves. Hence, John and the Moroccans are depicted as metaphors of change embodying the notion that when one is disturbed, one essentially changes.

Change disrupts stability; it undermines and questions the objectivity of reality and truth. Change complements the opposition to a fixed and essentialist identity, on which Bhabha and the deconstructionists agree. It should be noted however that though disruptions lead to change, such change could mean either progress or decline. In this instance, hybridity is manifested in the tension that the characters experience as they grapple with identity issues.

Long before the formulation of the concept of logocentrism, which is the belief that there is an ultimate reality or center of truth that can serve as the basis for all of a person's thoughts and actions, Aristotle had already introduced the principle of noncontradiction - an idea that would later be used as a tenet by the deconstructionists. This principle of noncontradiction questions the fixed idea of being and non-being since a thing cannot only either be or not be at the same time. There should be something in between known as becoming (Bressler, 1999). Therefore, to question and challenge the established center is for one to construct a new one. This thing that comes in between being and non-being based on the pattern set by deconstructionists becomes the product of disruptions and dislocation of the system called the 'hybrid idea'.

The disruption and ambivalence caused by the Western cultural system on the African practice of their native ontology have prompted the natives to (re)create their new local identity or, put another way, a new local identity is born out of the ongoing tension created by two opposing practices. African literature has been influenced by this disruption known as the third option - a new mode, a new society that undertakes the contrasting views on racism and anti-racism to bring about a society that condemns racism becoming an important subject of many contemporary African literary works. Moreover, African artists and writers have also combined different styles, even languages, modes, and genres to produce a hybrid work of art.

\section{Dismantling a Prevailing Worldview: Men's Power over Women's Bodies}

Upon the invention of the Myth of the Dark Continent, many Western explorers and authors painted a romantic depiction of Africa needing to be saved by audacious men of adventure. Part of this fabricated conundrum is painting Africa as a land of indolent savages, sexually immoral and demented people conditioning the mind of the explorers that their adventure is a battle between good (the West) and evil (Africa) and that their presence will help free these people from their old ways (Jarozs, 1992).

Looking at how the West tried to assign roles to Africa, one can readily see that this branding is open to contestation. Nonetheless, such unfair and fabricated branding can actually be dismantled by juxtaposing it with the images of the continent and its people that the African writers themselves have depicted in their literary works. To dismantle is to subvert, challenge, undermine, and question the prevailing ideologies or previously held worldviews of people in power (Bressler, 1999), which in this case, were perpetrated by the colonizing Westerners on the natives in the African Continent. 
Since hybridity is seen to challenge existing hierarchies and binarisms, it is also proper to look into where and how these binaries operate. The branding invented by the West which has resulted in binaries or dualism favorable to its people can be explored by the possibility of inverting these hierarchies or "natural order" to shape new knowledge about language and life and to examine the unstable relationship between elements in a binary operation. By identifying the binaries, one can expose the preconceived notion upon which people based their interpretation, and in reversing these binaries to challenge them, people can free themselves from the constraints of their prejudiced beliefs.

Binaries also reveal and strengthen Bhabha's (in Huddart, 2007) point about hybridity - that their reversal creates ambivalence similar to displacing the authority from its position of power. As such, this colonial discourse explores not only the issue of colonizer-colonized but power as a whole that includes aesthetic consciousness and sensibility of feminine tradition and women as subjects of power. In this context, men represent power - literally as male characters and figuratively as the power wielded by the West. Women, on the other hand, represent Africa as female characters and as a metaphor for the motherland.

The short story, The Stranger, presents the powerful West as creating the idea of its men going on a romantic journey to battle evil assigning themselves as the redeemers representing the good side. The Frenchman Andre is a man from the West, a learned and self-proclaimed savior who looks at the Moroccans as ignorant, primitive, and weak people who need to be saved and ruled by a dominant man like himself. Even though he considers himself entitled because he is a man from the West, reality tells him differently. The hierarchy in which Andre believes is questioned and therefore his assumed identity is challenged. As Farahbakhsh and Sheykhani (2018) put it, the ambivalence formed from this event destabilizes the stance of colonial authority and discloses the uncertainties and anxieties within colonial powers. The event subverts the very dominating culture and evokes a re-examination of the power structure. One could then ask: does Andre really represent power?; and do the people really need him as their savior?

To situate the above questions, one can look at how Andre is portrayed in the story. He is described upon his arrival in the Moroccan village as a "mere nobody, shabbily clothed, covered in mud and trembling in the storm from weakness and exhaustion (p. 107)." Though he left his village in the south of France poor and destitute, he still carries with him his proud blood. He ambitions to seize the power that Uncle 'Abd al-Salam (a wealthy landowner and a tribe leader) holds by usurping the latter's position in the village. His plan involves using his skills and intelligence to win over the people in the small Moroccan village. He realizes his goal when he assumes power after the old man dies having been chosen by the tribal leader himself to succeed him. Andre immediately becomes dictatorial, bringing French soldiers into the village and literally making everyone his slave despite earlier claiming that he has become one with the villagers having learned their ways. However, Andre's power is only momentary because the villagers have an uprising to protest against their oppression. He dies ironically in the hands of a most unlikely character, Fatima, a girl he believes to be weak and fragile. Thus, Andre is responsible for bringing out both the villagers' and Fatima's courage to fight against their oppression. Fatima expresses his ignominious end as follows:

\section{You hold power over this farm and others around it, near and far. But you can never have over our hearts. And so long as you are powerless to take away the contempt I feel, you are still as you were when you arrived, weak and exhausted! You are now in my hands - I, the simple farm-girl, (p.107).}

The preceding passage expresses Fatima's subversion of Andre's previous authority. Fatima who is the only daughter of Uncle Abd al-Salam is a passive character at the beginning until the middle part of the story acting simply as a spectator in their village. Her bravery comes to the fore after her brothers' arrest by Andre as well as after she witnesses the 
devastation of her paradise, her father's land, in the hands of the invaders:

The beauty of life was gone from the farm - that life which had been full of kindness, mercy, and love. The beautiful fertile land also was no more, that land which used to feed their bodies and souls at one same time, (p.106).

Fatima who is a triggered character exemplifies Pourgiv's (2012) claim that "[the] conversion of a woman is often perceived by the one experiencing it and not particularly as a transformation from an old self to a new one, but as the discovery of the authentic self that is there since the beginning that is forced into hiding by pressure from familial social structures... (p.3)" Fatima as female is conscious of her village's hierarchical tradition mainly adhering to her passive feminine role in the past. She only displays her hidden courage by taking matters into her own hands because of the absence or inability of the male members (father is dead; brothers are imprisoned) to stand up for their family.

With Andre's doom, the "natural order" of good against evil is subverted, making the supposed evil triumphant over the good ones. Andre's power proves superficial being totally dependent on his weapon. Once divested of it, he is now incapable of warding off the "evil" forces and is reduced to being a cowering man, according to Fatima:

And you are trembling with terror and fear despite your knowledge and your authority - because it is I who hold the weapon today. I have snatched it from you, you coward, to reveal you as a weak man cringing before a weak girl - Because a weak girl has a piece of steel in her hand, (pp. 107-108).

The gun they fought over can be a representation of Andre's imagined power whereby anyone who holds it holds the power. It has neither true master nor follower. Andre's power is just borrowed and thus could be taken away anytime. He aspires to rule over a small village but fails to have total control over it. Andre's undignified end can then be argued as the naivety of the western people in underestimating the fervor and the heart of the natives whom they have stereotyped as thoughtless, demented, and savage. It turns out in the end that Andre is the one who needs saving from his arrogance and ignorance. Clearly, the tension emanating from the clash of the two races and cultures creates a change that does not simply separate the powerful from the weak but involves the beginning of a new transcultural form. The village will never be the same again with the people directly witnessing the wickedness of Andre and his French soldiers. This event has produced a unique product: blended but is ever-changing - that is growth. As for Fatima, she becomes a woman who has power, not the old patriarchal power but a power to create, power to articulate, and power to transform lives (Friedman, 2006).

In Meeting in the Dark, John who is portrayed as a character struggling with his identity in the village can be argued as a representation of a hybrid. Bakhtin (1981) in his concept of hybridity presents two types of hybrid - intentional hybrid and unconscious or organic hybrid. In the second type, the combination remains mute and dormant, unresponsive to using the conscious contradictions and oppositions, and allows the union of two or more cultures forming it into a new one. John's position is the metaphor of the former (two points of view are not mixed but set against each other), which Young (in Castle, 1996) affirms when he points out that John's tension "enables a contestatory activity, a politicized setting of cultural differences against each other (p. 136)."

John, in the opening part of the story, is already introduced as a hybrid man - a Kenyan who knows his tradition but practices or rather is compelled to practice the new ways, the whites' ways. His father is a convert working as a strict and domineering clergyman and he is esteemed in Limuru for his adherence to the whites' ways. At the same time, he is still traditionally focused on maintaining his family's name as an exemplar of virtue. With his father's reputation, John has gained his own value and has built his own influence over the villagers. For a time, he enjoys his privileged position but the village elders expect John to practice and safeguard 
his old ways. The tension between the social and political systems disturbs and threatens John's status quo. He begins to question his identity but fails to realize that he is neither a native nor a foreigner and therefore a product of the tension between the imported culture from the West and the local way of life. The following passage, which expresses John's contradictory feelings towards Limuru, evokes the tension stemming from his being a hybrid:

\section{Limuru was a land of contrast and evoked differing emotions at different times. Once John would be fascinated and would yearn to touch the land, embrace it or just be on the grass. At another time he would feel repelled by the dust, the strong sun, and the pot-holed roads (p.99).}

His ambivalence towards Limuru suggests further that John has become a prisoner in his own comfort. But much of the pressure he feels is self-imposed. In everything he does, he always fears the damnation that he might suffer if he disgraces his family and betrays people's expectations of him as revealed in the following passage:

If only his struggle were just against the dust, the mist, the sun, and the rain, he might feel content... But there was the human element whose vices and betrayal of other men were embodied in the new ugly villages (p.99).

John's inner conflict is all-pervading. He becomes consumed with guilt when he gets Wamuhu pregnant out of wedlock because he knows he has betrayed everyone's expectations especially that of his father. In his desperation, he kills Wamuhu and his unborn child. His inner tension worsens after considering how his acts might affect his and especially his father's social and political status once everyone learns that he "has created and then killed."

It can be argued that John's suffering is caused by the accumulation of many different factors he inherited stemming from both his own home and his village ways. But his mental torture is mainly caused by his unwillingness to publicly acknowledge his relationship with Wamuhu: the villagers have only mere speculations while his family is completely clueless about it.

Wamuhu, a simple and traditional girl, turned John's position upside down. She is his girl who has known no other man and yet hidden. Just as he is about to leave for college, she becomes pregnant so she keeps reminding him of his promises to her: tell both of their parents about their relationship and eventually start a family as a married couple. But John is torn between leaving for Uganda to enter college as if nothing has happened and confessing to his father his sin of disgracing a girl. He decides to opt-out of his responsibility and offers Wamuhu money so they can end their relationship:

Look, Wamuhu. Let me give you money. You might then say that someone else was responsible. Lots of girls have done this. Then that man may marry you. For me, it is impossible. You know that (p.101).

Wamuhu refuses to be paid even after he increases his offer from two hundred to twenty thousand shillings. In the end, John kills her and their unborn child in their dark meeting place. His fear of damnation has become a reality and he even turns out worse than the young men in his village who left unmarried girls with fatherless children. In this sense, the killing of Wamuhu parallels the permanent loss of tradition in Limuru in as much as Wamuhu is one of the very few young people in the village adhering to tribal traditions; many of her generations have adopted the whites' ways. By killing her and their unborn baby, John contributes to the destruction of their old ways and signals his leaning towards assimilating the colonizers' culture.

Meanwhile, Jones' short story, A Man Can Try, explores the tensions brought about by the interplay of colonialism and human values. Subverted elements are also expressed in this short story. By presenting the two women in Tullock's life, Jones is able to differentiate the West from Africa from the vantage of two binaries: majority and minority, and powerful and weak. On one hand, Denise, Tullock's fiancée, is an English woman who is highly educated, sophisticated, and a visible member of a political party. She is intensely alert and 
has strong convictions perfectly embodying the values of the West. On the other hand, Marie is an African, black, illiterate, soft, and entirely devoted to Tullock obviously mirroring how the West perceives Africa weak and submissive. Therefore, the contrasting portrayals of the two women suggest the West's hierarchy of power: it has dominance and authority over Africa, which it perceives to be primitive and weak.

The protagonist, Tullock, is an Englishman but has not lived his old English life for eight years, embracing instead a relaxed and easy life in Africa with Marie. When he is compelled to get back home for good, he suddenly feels threatened. His situation in Africa has been so dramatically different from his office life in England. He never argues with Marie because he is always sure of her willing obedience while thinking of his life with Denise, he concludes that it would mean a "lifetime mental tug-of-war." Part of him does not want to exchange "the warmth and relaxation of Africa for the chilly, bracing England" but the other part does not want to disgrace his family. On his way home to England, he reflects on his relationship with Denise:

Doubts about their relationship came rushing into his mind. Doubts of the most fundamental kind. Did he really want to marry Denise? It did not matter. He had to (pp.120-121).

Tullock's struggles make him a different man from eight years ago but he always bears the stance of an Englishman that separates him from his co-workers in Africa. Like John in Meeting in the Dark, Tullock can be seen as a hybrid, displaced with a sense of discontinuity both in terms of time and space. He knows he will suffer but still chooses such a path:

that life with Denise would now have to be one long never-ending effort to live up to a life he no longer believed in ... but a man can try (p. 121).

The depiction of Marie as naive is stereotypical but her impact on Tullock's life subverts and challenges the "natural order," making the weaker woman the one holding real power over Tullock. Leaving her will cause him a lifetime sense of fragmentation.

Marie, like Wamuhu, is implicated by the distinction of human values and ethical norms she is forced to face. But unlike Wamuhu, Marie is a willing victim knowing fully that an Englishman does not see an African like her as equal. Wamuhu refuses to be paid in exchange for her pride and tradition while Marie willingly accepts the fact that Tullock is ending his connection with her and their child. Therefore, these two women represent the dichotomy of values in African colonial discourse as well as the African perception of how the West treats Africa.

African literature has embraced the many changes in its form as well as the evolution of the theme of historical struggle from liberation to a more optimistic revolutionary dimension. Works such as Anthony Hokororo's A Day Off (Tanzania) subtly present reversal of binary operations in a society that has been influenced by Western culture. Zale has been wife to Abdu for five years, marrying him after her mother's sudden death, and thus is saved from torments of solitude. As a wife, she takes care of everything at home. She has dutifully done her chores without complaints but being a "yes woman" for five years awakens her new consciousness and suddenly decides to take a "day off."

Zale's decision to leave the house and travel depicts her courage to challenge women's established position in society. Being a devoted wife has made her life dull and she has lost her initial excitement in their union as revealed in the passage:

earlier in their marriage, Zale could never resist kissing him awake at such moments. But now her mind registered only the fact that he was dead to the world and that he needed a shave (p132)."

Her boredom is further gleaned in the passage below:

Being married had been very great fun at first, looking after the house, making the curtains and learning to cook, Abdu had shown himself to be quite a contented 
husband. But... it seems that he is too contented (p.135).

For Zale, to take the day off is revolutionary - a challenge to the "natural order." Her day off gives her time to contemplate about herself, her life with Abdu, and a chance to meet other people, which she has not experienced in the last five years. In return, Zale's note also brings Abdu his own realization and a whole new consciousness: "I've decided to take a day off... There's rice and meat in the cupboard if I'm not back for supper (p.136)." This simple note elicits new learning for Abdu who honestly tells her later, "I heard the train coming... Knew you'd be along, so - ... Oh the heck with it, Zale, who wants to eat alone (p.137)?" His reaction is a triumph for Zale who suddenly feels older and wiser than her husband has been able to put into action what she longed to do. Acting as an unconventional woman freed her from the constraints of tradition as her husband represents both power and tradition. Confronted with his wife's absence and sudden withdrawal from her daily role, Abdu quickly realizes her immeasurable importance in his life.

Unlike the characters of Wamuhu and Marie whose bodies are desecrated by men of power through being impregnated and then left behind (Marie) or repudiated (Wamuhu), Zale's act in cutting her hair does not represent a desecration of her body but the commencement of her new knowledge of the transformative power of the female body. Thus, the effect of the ambivalence in Zale's surroundings is nurturing and not exploitative of her body. Zale is a hybrid who, according to Jamshidian (2019), was once repressed and marginalized but finally asserts her voice and therefore survives the authority of the dominant power while preserving her local identity.

In Coffee for the Road by La Guma, the issue of apartheid is symbolically illustrated through the mother's ill-fated encounter with a racist. The mother, in this instance, tries to defy a social system wherein women of color like her expects equal treatment from their white counterpart but is overwhelmed by the harsh reality of South Africa's social structure.
When the story opens, the mother is driving her two children on a long road to Cape Town where her husband is waiting. She is trying to speed up the journey to reach the new city in the afternoon of the following day but still has to contend not only with managing the road but also with the random needs of her very young children such as sandwiches, water and even answering their gibberish questions. Halfway in their journey, the mother needs to stop by a café to fill her empty flask with coffee for the road as well as to get drinks for her children who have been continuously begging for one. The mother enters the café confidently and orders her coffee and is totally unprepared by the rude response from the café attendant:

Coffee. My Lord Jesus Christ!" The voice screeched." A bedamned coolie girl in here... Coolies, Kaffirs and Hottentots outside," she screamed. "Don't you bloody well know? And you talk English, too hey! (p.127).

The startled mother immediately snaps and smashes the flask she is carrying onto the café attendant's forehead as she cries in rage, "Bloody white trash. Coolie yourself (p.128)!" In this part, the mother has surely taken charge of the situation, but what awaits her is a complete turn of events when a policeman is already waiting by the roadside to arrest her. Without further resistance, the mother follows the police and drives back to where they have started.

As a whole, the short story can be divided into two vital parts. First, La Guma shows how women as represented by the mother can also do things that are usually done by men such as driving. The mother is even speeding on the road when the story opens. This depicts her as someone independent and dependable as her husband has gone ahead to Cape Town expecting her to follow with their children and their remaining things. The way she is upfront in confronting the white woman who discriminates against her reveals her unconventional and empowered character but the second part of the story presents the antithesis of her whole journey. No matter how she is empowered to create a new future, she cannot easily do so with institutionalized obstructions set in place for locals like her. 
This means that though women may have personal empowerment they will fail to realize their potential if society does not change to provide a supportive environment for them such as institutionalizing policies that will end racism and sexism.

The abuse of women in the analyzed short stories such as Fatima being nearly sexually assaulted by Andre, Wamuhu being impregnated and killed by John, and Marie being impregnated and left by Tullock aptly represent the defilement of Africa by its colonizers but yet still thriving, recreating herself to be a positive source of strength just like how the mother stands up against the white café attendant and how Zale takes charge of rediscovering herself despite both having to navigate themselves within the entrenched patriarchal system. All the five women characters have challenged the pervading monolithic power of men creating ambivalence that has resulted in the birth of the idea of a hybrid.

\section{Hybridized Identity: The Shape of the New African Woman}

The concept of hybridity is in and of itself connected to the idea of identity. Ashcroft, Griffiths, and Tiffin (1989) observe that a colonized culture such as Africa underwent a phenomenon that involves a "dialectical" relationship developed from Western cultural systems and native system, which in turn (re)creates a new local identity. What comprises this new local identity is a combination of a harsh reality of the interaction of the colonial hegemonic system and the colonized depraved and twisted peripheries. This system is at work when John and Wamuhu in Meeting in the Dark, try to fight the intensifying effect of this structure on their village and themselves. As Wamuhu tries to save her dignity and John attempts to conceal his sin, they end up destroying each other. This means that this new identity is a result of the dislocation of the old system and the disruption of the new one. Fatima in The Stranger acquires her new identity as she evolved from a dormant to an active character, awakened by the harsh reality of slavery. Andre compels Fatima to recreate an identity that ultimately overwhelms him and destroys his very power. Therefore, Fatima evolves to be a hybrid who, according to Ghasemi, Sasani, and Nemati (2018), destroys the stance of colonial authority.

This (re)created identity is invoked alongside the Negritude movement, an ideological position that holds Black culture to be independent and valid on its own terms and an affirmation of the African cultural heritage to forge a third option (Young, in Castle, 1996). This envisioned (re)created identity is what the mother in Coffee for the Road has already conceived and practiced but hers is a displaced consciousness in an environment still steep in colonial practices. This third option is a new way, a brand-new society where the contrasting values of racism and anti-racism would bring about a society devoid of racism and a new human-centered discipline. Meaning, this ideal third option is still just an illusion for an awakened African in a society that does not yet acknowledge it. This is also true with Marie in A Man Can Try who for eight years is enchanted by the idea that a Western man would take a black woman seriously. After the disillusionment, she just accepts the "natural order's" verdict that there is a need for a more in-depth people's enlightenment to place both colonizers and colonized discourses on the same traction.

Even though being a hybrid could be a result of the difficult and painful history of interracial identity intertwined with issues of choosing one's affiliations or having one's affiliations thrust upon a person (Radhakrishnan, 1996), it is not always equated with confusion and uncertainty of identity. Instead, at some point, it creates a space to rediscover oneself. Zale in The Day Off is a Tanzanian woman empowered enough to give herself time to unwind from the deadening domestic servitude she has carried out every single day for years. Though Tanzanians still practice the patriarchal system in their households, the presence of Western ways is surfacing not only through the facilities around the city but also through the values of the locals. Zale is a revitalized woman, a modern one who does not see anything detrimental in embracing these modern practices especially that the feeling of liberation made her better understand her 
relationship with her husband and her own identity. Zale is among those people, according to Bhabha (1996), of multiple identities and mixed origins who experience their hybridity with more or less serenity and whom society welcomes with varying degrees of benevolence.

Ultimately, hybridity is a cultural effect of globalization (Bhabha, 1996). It is intrinsically linked to the notion of identity held by multicultural individuals, migrants, and diasporic communities. It does not literally declare war on the past but challenges the consequences of the past that are exploitative and the logic of permanent presence, or of never-changing identity of the colonial discourse (Mizutani, 2013). Part of this reality is the undermining of patriarchal power and influence of the West in Africa and its people, and the part that has made inroads into such a reality comes from former repressed voices and previously invisible bodies of the women characters.

\section{Conclusion}

The inclusion and emphasis on women characters in short stories can be interpreted to mean that there is an impossibility of the separation of the arts and the imagination from a "socially, sexually, and historically positioned self (Friedman, 2006). The portrayal of women characters in the selected five short stories reveals a unique tradition and, at the same time, a new consciousness in African Literature reflecting the concept of female aesthetics. This woman metaphor represents the lost motherland, the vanished nation, or of a powerful but neglected women's culture. In this sense, the use of women's bodies in the short stories does not only point to the issue of gender oppression but also to power that is disrupting and slowly dismantling the long-entrenched patriarchal stance forcing the male characters to question their current worldview and position thus realizing their own hybridity. Overall, the contemporary African literature on women depicts a hybridized identity in the shape of the new African woman who has acquired her own power, distinct from the still prevailing patriarchal power, to create, articulate, and transform lives, consequently proving that the so-called Dark Continent is nothing but a myth.

\section{References}

Ashcroft, B., Griffiths, G., \& Tiffin, H. (1989). Post-colonial studies: the key concepts. New York, USA: Routledge.

Bakhtin, M. (1981). Discourse in the novel. In Mikhail Bakhtin, The dialogic imagination: Four essays by M.M. Bakhtin (ed. by Michael Holquist, trans. by Caryl Emerson Michael Holquist, pp.259-422). Austin: University of Texas Press.

Bhabha, H. K. (1994). The location of culture. London, UK: Routledge.

Bhabha, H. K. (1996). Culture's in-between. In Stuart Hall \& Paul du Gay (Eds.), Questions of cultural identity (pp.53-60). London: Sage Publications

Bressler, C. E. (1999). Literary criticism: an introduction to theory and practice. $\left(2^{\text {nd }}\right.$ Ed.). New Jersey: Prentice Hall.

Radhakrishnan, R. (1996). Diasporic mediations: Between home and location. Minneapolis, USA: University of Minnesota Press

Brantlinger, P. (1985). Victorians and Africans: The genealogy of the myth of the dark continent. Critical Inquiry 12 (pp.166168). DOI: $10.86 / 448326$

Castle, D. (1996). Robert J. Young - Colonial desire: Hybridity in theory, culture, and race. Left History: An Interdisciplinary Journal of Historical Inquiry and Debate. 4. DOI:10.25071/1913-9632.6992.

Diop, A. C. (1997). On African literature. In Okafor, V. Toward an Africological Pedagogical Approach to African Civilization. Journal of Black Studies, 27(3), 299-317. Retrieved from http://www.jstor.org/stable/2784780

Farahbakhsh, A. \& Sheykhani, R.R. (2018). Homi K. Bhabha's concept of ambivalence in J. M. Coetzee's disgrace. Pertanika Journal of Social Sciences and Humanities. 26. pp. 859-872. Retrieved from https://www.researchgate.net/publicati on/326320533 Homi K Bhabha\%27s concept_of_ambivalence_in_J_M_Coetzee $\% 27$ s_disgrace

Friedman, E. (2006). Feminism, masculinity, and nation in Joyce Carol Oates's fiction. Studies in the Novel, 38(4), pp 478-493. Retrieved from www.jstor.org/stable/29533787 
Ghasemi, P., Sasani, S., \& Nemati, F. (2018). Third space, hybridity, and colonial mimicry in fugard's blood knot. Khazar Journal of Humanities and Social Sciences 21- 1, pp. 34-52. DOI: 10.5782/22232621.2018.21.1.3

Guignery, V., Pesso-Miquel, C., \& Specq, F. (2011). Hybridity: forms and figures in literature and the visual arts. Cambridge Scholars Publishing, pp.380.

Huddart, D. (2007). Hybridity and cultural rights: Inventing global citizenship. Reconstructing hybridity: post-colonial studies in transition. Ed. Joel Kuortti and Jopi Nyman. Studies in Comparative Literature, $51 . \quad$ DOI: 10.1163/9789401203890_003

Jamshidian, S. (2019). Local Heritage/ Global Forces: Hybrid Identities in Le Guin's The Telling. Gema Online Journal of Language Studies. 19. 96-110. DOI: 10.17576/gema2019-1904-05.

Jarosz, L. (1992). Constructing the Dark Continent: Metaphor as Geographic Representation of Africa. Geografiska Annaler: Series B, Human Geography, 74(2), 105-115, DOI: 10.1080/04353684.1992.11879634

Mizutani, S. (2013). Hybridity and History: A Critical Reflection on Homi K. Bhabha's Post- Historical Thoughts. Ab Imperio (4), pp. 27-48. DOI:10.1353/imp.2013.0115.

Sasani, S. (2015). A Postcolonial Reading of Athol Fugard's "Master Harold" ... and the Boys. Mediterranean Journal of Social Sciences, $\quad 6(3 \quad \mathrm{~S} 2), \quad 458 . \quad$ DOI: 10.5901/mjss.2015.v6n3s2p458

Mambrol, N. (2016, April 8). Homi Bhabha's concept of hybridity / Literary Theory and Criticism. Retrieved on August 13, 2019 from

https://literariness.org/2016/04/08/ho mi-bhabhas-concept-of hybridity/

Yazdiha, H. 2010. Conceptualizing Hybridity: Deconstructing Boundaries through the Hybrid. Formations 1-1. Retrieved from https://academicworks.cuny.edu/gc_pub $\mathrm{s} / 314$ 